\title{
Can tortoises facilitate the germination of plants with dry fruits? A simulation of the effects of Chelonoidis carbonarius (Testudines: Testudinidae) on the germination of Leucaena leucocephala (Fabaceae)
}

\author{
João Fabrício Mota Rodrigues ${ }^{1,2,5}$ \& Sâmia Paiva de Oliveira ${ }^{3,4}$
}

\begin{abstract}
Ingestion of seeds by vertebrates may influence seed germination and dispersion. However the mechanisms responsible by these effects and the importance of turtles in these interactions are still poorly understood. This study aims to evaluate how Chelonoidis carbonarius influences the germination process of Leucaena leucocephala using an experiment conducted at the Federal University of Ceará, Fortaleza-CE, Brazil, that simulates the passage of the seeds of this plant through the digestive tract of $C$. carbonarius: stomach acidic condition and seeds sown in feces. We demonstrated that sowing the seeds in feces of Chelonoidis carbonarius has a negative effect on the germination of Leucaena leucocephala, decreasing the germination speed index of the seeds, while the acidic conditions have a neutral one. This study is a first attempt to understand how turtles and tortoises may influence the seed germination, and the implications of these findings in natural environments deserve further investigations. Key words: acidic conditions, germination speed index, invasive species, simulation, turtles.

\section{Resumo}

A ingestão de sementes por vertebrados pode influenciar a germinação e a dispersão dessas sementes, porém pouco se sabe sobre os processos responsáveis por essa influência e sobre a importância dos quelônios nessas interações. Este estudo tem como objetivo avaliar como Chelonoidis carbonarius influencia o processo de germinação de Leucaena leucocephala usando um experimento conduzido na Universidade Federal do Ceará, Fortaleza-CE, Brasil, que simula a passagem das sementes dessa planta através do trato digestivo de $C$. carbonarius: condições ácidas do estômago do animal e a semeadura das sementes nas fezes. Foi demonstrado que a semeadura das sementes nas fezes de Chelonoidis carbonarius tem um efeito negativo sobre a germinação de Leucaena leucocephala, diminuindo o índice de velocidade de germinação das sementes, ao passo que as condições ácidas tem um efeito neutro. Este estudo é uma primeira tentativa de entender como os jabutis podem influenciar a germinação das sementes e as implicações destes resultados em ambientes naturais merecem mais investigações.
\end{abstract}

Palavras-chave: condições ácidas, índice de velocidade de germinação, espécies invasoras, simulação, quelônios.

\section{Introduction}

Ingestion of seeds by vertebrates may affect seed germination, but the processes related to this influence is a topic still poorly understood (Traveset 1998). Turtles and tortoises are examples of animals that have fruits in their diets, and some studies found that these animals may influence the germination and dispersal of plants that they eat (e.g., Liu et al. 2004; Strong \& Fragoso 2006; Jerozolimski et al. 2009; Padgett et al. 2010; Blake et al. 2012). The ingestion of seeds by these animals may increase or decrease the number of germinated seeds and the germination speed, which vary according to the plant species (Liu et al. 2004). Tortoises can act in this germination course, accumulating seeds and

\footnotetext{
${ }^{1}$ Universidade Federal de Goiás, Inst. Biociências, Depto. Ecologia, Av. Esperança s/n, 74001-970, Goiânia, GO, Brasil.

${ }^{2}$ Universidade Federal do Ceará, Núcleo Regional de Ofiologia (NUROF-UFC), Centro de Ciências, Av. Mister Hull, 60440-554, Fortaleza, CE, Brasil.

${ }^{3}$ Instituto Federal de Educação, Ciência e Tecnologia do Ceará, Campus Crateús, Av. Geraldo Marques Barbosa s/n - Venâncios, 63700-000, Crateús, CE, Brasil.

${ }^{4}$ Universidade Federal do Ceará, Programa de Pós-graduação em Ecologia e Recursos Naturais, Centro de Ciências, Depto. Biologia, Av. Mister Hull, 60455-760, Fortaleza, CE, Brasil.

${ }^{5}$ Author for correspondence: fabriciorodrigues303@gmail.com
} 
placing them in a medium rich in nutrients (feces), removing germination inhibitors (Birkhead et al. 2005), or increasing seed coat permeability using the acidic composition of gastric secretions (Gardener et al. 1993).

Chelonoidis carbonarius (Spix 1824), popularly known as "Red-footed Tortoise", is an herbivorous tortoise widely found in the Brazilian territory (Rueda-Almonacid et al. 2007). These animals mainly eat leafy vegetables, fleshy fruits (Wang et al. 2011), dry fruits of legumes (Birkhead et al. 2005), and they disperse some plants in the Amazon Forest (Strong \& Fragoso 2006). In captive conditions, we observed that individuals of $C$. carbonarius also freely eat many parts of Leucaena leucocephala (Lam.) de Wit, a legume plant that is very common in the area where these captive tortoises forage. However, so far, no study has evaluated how this tortoise may influence the germination of plants with dry fruits, such as L. leucocephala.

Leucaena leucocephala, within the Fabaceae family, is an exotic legume plant, native from Mexico and geographically distributed across the tropical region (Souza et al. 2007). This species has been considered as invasive in many countries on all continents (except Antarctica) and is cited by IUCN (International Union for Conservation of Nature) as one of the 100 most aggressive invasive species on the planet (GISD - Global Invasive Species Database 2000). This species has natural seed dormancy caused by seed coat impermeability to water (Teles et al. 2000; Fonseca \& Jacobi 2011; Tadros et al. 2011), common among tropical species and found in most of the legumes (Kigel \& Galili 1995). Therefore, the exposure to acidic conditions, a common dormancy breaking mechanism, may accelerate the germination rate of this species.

The distribution of invasive species in the invaded areas is influenced by various processes, such as introduction effort, climate matching, species traits and global trade, and in plants, dispersion by vertebrates is a trait positively associated with the success of the invaders (e.g., Lloret et al. 2005; Banks et al. 2015; Mahoney et al. 2015). This understanding is the first step to properly forecast the invasion spread and to be able to control it. Considering this conservation issue and the observations regarding the feeding ecology of $C$. carbonarius reported before, our study aimed to evaluate how this tortoise influences the germination process of $L$. leucocephala using an experiment that simulates the passage of its seeds through the digestive tract of the tortoise (including exposition to acidic conditions and immersion in feces). Besides simulating the passage through the digestive tract, we also evaluated the effects of acidic conditions and immersion in feces separately. This approach is a novelty of our study, because we are trying to understand the processes related to the seed germination rather than simply evaluating the germination values of eaten seeds.

\section{Material and Methods}

Seeds of Leucaena leucocephala were equally harvested from six plants randomly chosen in January 2013 at the Federal University of Ceará, Fortaleza-CE, Brazil ( $3^{\circ} 45^{\prime} \mathrm{S}$ and $39^{\circ} 02^{\prime}$ ' $\mathrm{W}$, datum WGS84). The area has an average elevation of $16 \mathrm{~m}$ above sea level and a warm subhumid tropical climate according to the Köppen classification (Reddy 1983) with average annual rainfall of $1,338 \mathrm{~mm}$ and average temperature of $26-28^{\circ} \mathrm{C}$. The rainy season is concentrated from January to May (INMET 2014).

The weight of 1,000 seeds was $40.17 \mathrm{~g}$ with $15.3 \%$ moisture. The seeds were separated in four treatments: Treatment 1 (control): seeds kept in sand substrate for germination without dormancy breaking; Treatment 2: Seeds immersed in a solution of hydrochloric acid $(\mathrm{HCl})$ and distilled water at $\mathrm{pH} 2.0$ for $30 \mathrm{~min}$ (Brasil, 1992) and taken to germination in sand substrate; Treatment 3: seeds collected and sown in the feces of the animal for germination; Treatment 4: seeds collected and sown in the feces for germination after immersion in $\mathrm{HCl}$ solution for $30 \mathrm{~min}$. Treatments with chemical scarification were selected in order to examine whether exposure to $\mathrm{HCl}$ at concentration $=0.01 \mathrm{~mol} / \mathrm{L}$ or $\mathrm{pH} 2.0$, a concentration similar to that found in the stomach of tortoises (Barboza 1995), could act as a mechanism for dormancy breaking. The feces used in the experiment were fresh and humid, and they were obtained from one individual of C. carbonarius kept in the Núcleo Regional de Ofiologia da Universidade Federal do Ceará (NUROF-UFC). We used the treatments with only $\mathrm{HCl}$ and only feces in order to evaluate which of these processes most influenced the germination of L. leucocephala seeds that are eaten by C. carbonarius, which would face both steps (equivalent to treatment 4).

Each treatment had four replicates with 25 seeds each (= 400 seeds). Each replicate was 
placed in moist chambers containing washed and autoclaved river sand at constant temperature of $25^{\circ} \mathrm{C}$ and with $20-\mathrm{W}$ fluorescent lamps, giving a radiant flux of about $50 \mathrm{~mol} \mathrm{~m} \mathrm{~m}^{-2} \mathrm{~s}^{-1}$ (Rosa \& Ferreira 1998) for 12 hours/day. The experiment was kept for 30 days with daily observations and followed the recommendations of the Rules for Seed Analysis (Brasil 1992). Seeds with root protrusion of $0.5 \mathrm{~cm}$ were considered as germinated, a cut-off commonly used in other germination studies (e.g., Maguire 1962; Paulsen \& Högstedt 2002; Souza et al. 2007).

We evaluated differences in cumulative germination (cumulative proportion of seeds germinated in each day) among the four treatments using Generalized Linear Models (GLM) with Binomial error family and logit link function, because the response variable range between 0 and 1 (Guillén et al. 2009; Benítez-Malvido et al. 2014). The model had cumulative germination as a response variable and time (the number of days since the seeds were sowed), time ${ }^{2}$, treatment, time $\times$ treatment, time $^{2} \times$ treatment as $^{2}$ explanatory variables. This linear model provides three parameters for each treatment: 1) starting germination (the regression intercept), 2) initial germination rate, and 3) variation in germination rate; and we used Analysis of Deviance with chi-square tests to evaluate if these parameters varied among the treatments (Guillén et al. 2009; Benítez-Malvido et al. 2014). Differences among the treatments were evaluated using $\mathrm{Z}$ tests and a significance level of $5 \%(\mathrm{P}<0.05)$. These analyses were performed using the $\mathrm{R}$ software ver. 3.1.2 (R Core Team 2014).

We also calculated the Germination Speed Index (GSI), using daily counts of germinated seeds at 30 days after sowing, according to the equation proposed by Maguire (1962): GSI $=\Sigma(\mathrm{ni} / \mathrm{ti})$, where: $\mathrm{ni}=$ number of seeds that germinated in time ' $i$ ', and $t i=$ time after conducting the test. We used this evaluation to infer about seed vigor and germination speed after dormancy break.

\section{Results}

Cumulative germination percentages were low in all the treatments (Fig. 1). We observed that germination percentages were higher and similar in treatments 1 and 2 when compared to the other treatments, with maximum values of 32.5 and $37 \%$ respectively. The lowest value (14\%) was found in treatment 4.
We observed that the interaction time ${ }^{2}$ $\times$ Treatment was not significant, indicating that there is no difference in the variation of germination rate among the treatments (Tab. 1). Because of this, we ran a second model excluding this variable to evaluate the treatment effects. In general, we observed that treatments using feces had lower starting germination values than the others, and the treatment 3 had the highest initial germination rate (Fig. 1).

There was no difference between the treatment using $\mathrm{HCl}$ (treatment 2) and the control (treatment 1) in GSI. However, the use of feces (treatment 3 ) and its combination with $\mathrm{HCl}$ (treatment 4) provided a reduction in germination speed, which represents a delay in the germination process in these treatments (Fig. 2).

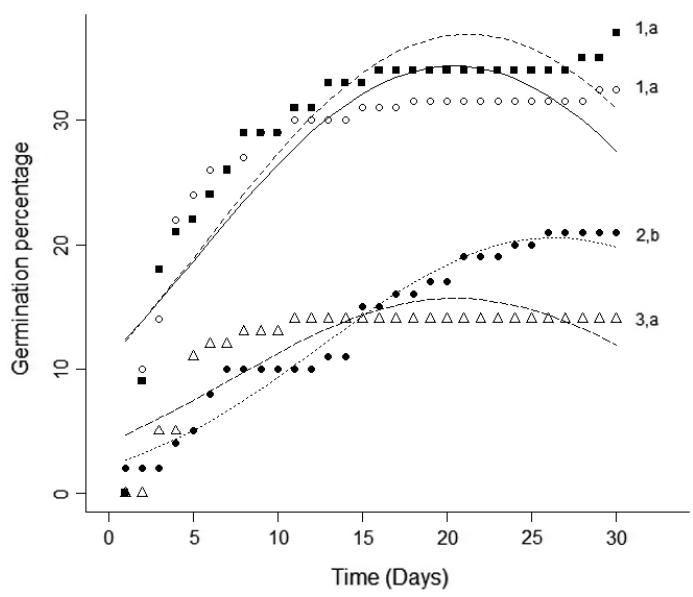

Figure 1 - Accumulated germination percentage of Leucaena leucocephala seeds throughout the experiment. Open circles = treatment 1: control; dark squares $=$ treatment 2 : immersion of seeds in a solution of hydrochloric acid $(\mathrm{HCl})$ and distilled water at $\mathrm{pH} 2.0$ for $30 \mathrm{~min}$; dark circles = treatment 3: seeds collected and sown in Chelonoidis carbonarius feces for germination; and open triangles $=$ treatment $4:$ seeds collected and sown in $C$. carbonarius feces for germination after immersion in $\mathrm{HCl}$ solution for $30 \mathrm{~min}$. Different numbers represent differences in the intercept (starting germination) among the treatments; lower case letters represent differences in initial germination rate among the treatments. Continuous line $=$ treatment 1 ; dashed line $=$ treatment 2 ; dotted line $=$ treatment 3 ; long dashed line $=$ treatment 4 . 
Table 1 - Analysis of deviance performed to evaluate the significant predictors in our model using chi-square tests. The response variable was the accumulated germination percentage of Leucaena leucocephala seeds in each day of the experiment, and the explanatory variables were treatment, time and time ${ }^{2}$.

\begin{tabular}{lccc}
\hline Explanatory variable & Deviance & Df & P \\
\hline Time & 192.40 & 1 & $<0.001$ \\
Time $^{2}$ & 82.92 & 1 & $<0.001$ \\
Treatment & 480.22 & 3 & $<0.001$ \\
Time $\times$ Treatment & 25.04 & 3 & $<0.001$ \\
Time $^{2} \times$ Treatment & 0.48 & 3 & 0.92 \\
Model $_{\text {Residual }}$ & 781.07 & 11 & \\
Total & 116.33 & 108 & \\
\hline
\end{tabular}

\section{Discussion}

We expected that the $\mathrm{HCl}$ at $\mathrm{pH} 2.0$, also present in the stomach of tortoises (Barboza 1995), would accelerate and facilitate the germination process due to an increase in seed permeability, but it was not confirmed by our results. We should emphasize, however, that germinative capacity was maintained even after exposing the seeds to $\mathrm{HCl}$. This maintenance of germination is common in seeds eaten by turtles and tortoises (Jerozolimski et al. 2009; Kimmons \& Moll 2010). The neutral effect of acidic conditions on seed germination could suggest that $C$. carbonarius could disperse seeds of L. leucocephala, because the animal could transport seeds of this plant for long distances after eat them, and they would still be able to germinate. This mechanism was already suggested by some authors for other species of turtles and tortoises (Jerozolimski et al. 2009; Kimmons \& Moll 2010; Padget et al. 2010). Seeds ingested by chelonians usually have low damage percentage (Kimmons \& Moll 2010; Padget et al. 2010), reinforcing the neutral effect on germination rates highlighted before.

It was expected that the animal's feces would increase the germination of $L$. leucocephala due to the supply of water and nutrients, acting as a fertilizer (Traveset \& Verdú 2002). The highest initial germination rate observed for the treatment 3 (Fig. 1) may be related to an excess of nutrients or a progressive liberation of germination inhibitors in feces (Paulsen \& Högstedt 2002), which initially stimulates seedling emergence of the germinated seeds, but in this case did not ensure higher accumulated germination or higher germination speed over time (Figs. 1, 2). The lowest germination speed indexes observed for treatments that simulated ingestion of $L$. leucocephala seeds by $C$. carbonarius allow us to state that there was a delay in germination processes. A decrease in germination values was also observed in seeds ingested by other turtles and tortoises (Liu et al. 2004; Kimmons \& Moll 2010). Fungal infection was observed in treatments using feces as substrate, which may have influenced their results. However, fungal growth in seed samples deposited in fecal material may be considered normal, because this substrate has several natural contaminants, and germination chamber has conditions of temperature, humidity, and photoperiod that favor such proliferation (Ferreira 1989).

Data obtained in the laboratory may not represent field conditions due to the complexity of factors that influence the biological processes of germination (Floriano 2004). Therefore, in the future, it would be important to replicate this experiment in a natural environment. It would be also interesting to perform a palatability analysis in these future studies in order to evaluate how often C. carbonarius prefer to eat dry fruits, such as those from $L$. leucocephala, instead of fleshy fruits in

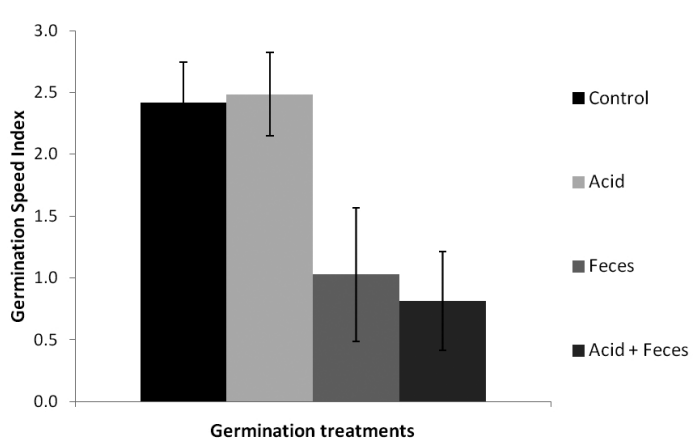

Figure 2 - Germination speed index (GSI) of Leucaena leucocephala seeds after 30 days. Control = treatment 1 (control), Acid = treatment 2 (immersion of seeds in a solution of hydrochloric acid $(\mathrm{HCl})$ and distilled water at $\mathrm{pH} 2.0$ for $30 \mathrm{~min}$ ), Feces $=$ treatment 3 (seeds collected and sown in Chelonoidis carbonarius feces for germination) and Acid + Feces $=$ treatment 4 (seeds collected and sown in C. carbonarius feces for germination after immersion in $\mathrm{HCl}$ solution for $30 \mathrm{~min})$. Error bars represent the standard errors of the means $(n=4)$. 
natural conditions. This test was not performed in our study because we had access to only one individual of the Red-footed Tortoise, which could produce a biased result of food preference.

We demonstrated that sowing the seeds in feces of Chelonoidis carbonarius has a negative effect on the germination of Leucaena leucocephala, decreasing the germination speed index of the seeds, while the acidic conditions have a neutral one. This study is a first attempt to understand how turtles and tortoises may influence the seed germination, and the implications of these findings in natural environments deserve further investigations.

\section{Acknowledgments}

We are grateful to Susana Churka Blum, for English revision and suggestions on the manuscript. We also thank three anonymous reviewers, for giving valuable comments in this manuscript.

\section{References}

Banks, N.C.; Paini, D.R.; Bayliss, K.L. \& Hodda, M. 2015. The role of global trade and transport network topology in the human-mediated dispersal of alien species. Ecology Letters 18: 188-199.

Barboza, P.S. 1995. Digesta passage and functional anatomy of the digestive tract in the desert tortoise (Xerobates agassizii). Journal of Comparative Physiology B 165: 193-202.

Benítez-Malvido, J.; González-Di Pierro, A.M.; Lombera, R.; Guillén, S. \& Estrada, A. 2014. Seed source, seed traits, and frugivore habits: implications for dispersal quality of two sympatric monkeys. American Journal of Botany 101: 970-978.

Birkhead, R.D.; Guyer, C.; Hermann, S.M. \& Michener, W.K. 2005. Patterns of folivory and seed ingestion by gopher tortoises (Gopherus polyphemus) in a southeastern pine savanna. The American Midland Naturalist 154: 143-151.

Blake, S.; Wikelski, M.; Cabrera, F.; Guezou, A.; Silva, M.; Sadeghayobi, E.; Yackulic, C.B. \& Jaramillo, P. 2012. Seed dispersal by Galápagos tortoises. Journal of Biogeography 39: 1961-1972.

Brasil. 2009. Regras para análise de sementes. Ministério da Agricultura e Reforma Agrária. Brasília: SNDA/DNDV/CLAV. Available at <http://www. agricultura.gov.br/arq_editor/file/2946_regras analise_sementes.pdf $>$. Access on 31 May 2015.

Ferreira, F.A. 1989. Patologia florestal: principais doenças florestais no Brasil. Sociedade de Investigações Florestais, Viçosa. 570p.

Floriano, E.P. 2004. Germinação e dormência de sementes florestais. Anorgs, Santa Rosa. 19p.
Fonseca, N.G. \& Jacobi, C.M. 2011. Desempenho germinativo da invasora Leucaena leucocephala (Lam.) de Wit. e comparação com Caesalpinia ferrea Mart. ex Tul. e Caesalpinia pulcherrima (L.) Sw. (Fabaceae). Acta Botanica Brasilica 25: 191-197.

Gardener, C.J.; Mcivor, J.G. \& Jansen, A. 1993. Passage of legume and grass seeds through the digestive tract of cattle and survival in faeces. Journal of Applied Ecology 30: 63-74.

Global Invasive Species Database-GISD. 2000. 100 of the world's worst invasive alien species: a selection from the global invasive species database. Available at $<$ http://www.issg.org/database/species/reference files/100English.pdf $>$. Access on 31 May 2015.

Guillén, S.; Benítez, J.; Martínez-Ramos, M. \& Casas. A. 2009. Seed germination of wild, in situ managed, and cultivated populations of columnar cacti in the Tehuacán-Cuicatlán Valley, Mexico. Journal of Arid Environments 73: 407-413.

INMET. 2014. Instituto Nacional de Meteorologia: dados de estações automáticas. Available at <http://www. inmet.gov.br/portal/>. Access on 31 May 2015.

Jerozolimski, A.; Ribeiro, M.B.N. \& Martins, M. 2009. Are tortoises important seed dispersers in Amazonian forest? Oecologia 161: 517-528.

Kigel, J. \& Galili, G. 1995. Seed development and germination. Marcel Dekker, New York. 853p.

Kimmons, J.B. \& Moll, D. 2010. Seed dispersal by red-eared sliders (Trachemys scripta elegans) and common snapping turtles (Chelydra serpentina). Chelonian Conservation and Biology 9: 289-294.

Liu, H.; Platt, S.G. \& Borg, C.K. 2004. Seed dispersal by Florida box turtle (Terrapene carolina bauri) in pine rockland forests of the lower Florida Keys, United States. Oecologia 138: 539-546.

Lloret, F.; Médail, F.; Brundu, G.; Camarda, I.; Moragues, E.; Rita, J.; Lambdon, P. \& Hulme, P.E. 2005. Species attributes and invasion success by alien plants on Mediterranean islands. Journal of Ecology 93: 512-520.

Maguire, J.D. 1962. Speed of germination-aid in and evaluation for seedling emergence and vigour. Crop Science, Madson 2: 176-177.

Mahoney, P.J.; Beard, K.H.; Durso, A.M.; Tallian, A.G.; Long, A.L.; Kindermann, R.J.; Nolan, N.E.; Kinka, D. \& Mohn, H.E. 2015. Introduction effort, climate matching and species traits as predictors of global establishment success in non-native reptiles. Diversity and Distributions 21: 64-74.

Padgett, D.J.; Carboni, J.J. \& Schepis, D.J. 2010. The dietary composition of Chrysemys picta picta (eastern painted turtles) with special reference to the seeds of aquatic macrophytes. Northeastern Naturalist 17: 305-312.

Paulsen, T.R. \& Högstedt, G. 2002. Passage through bird guts increases germination rate and seedling growth in Sorbus aucuparia. Functional Ecology 16: 608-616. 
R Core Team. 2014. R: a language and environment for statistical computing. R Foundation for Statistical Computing, Vienna. Disponível em < http://www.Rproject.org/>. Acesso em 21 julho 2016.

Reddy, S.J. 1983. Climatic classification: the semiarid tropics and its environment-a review. Pesquisa Agropecuária Brasileira 18: 823-847.

Rosa, S.G.T. \& Ferreira, A.G. 1998. Germinação de sementes de espécies medicinais do Rio Grande do Sul: Bromelia antiacantha Bert., Cuphea carthagenesis (Jacq.) Mccbride e Talinum patens (Jacq.) Willdenow. Acta Botanica Brasilica 12: 515-522.

Rueda-Almonacid, J.V.; Carr, J.L.; Mittermeier, R.A.; Rodriguez-Marecha, J.V.; Mast, R.B.; Vogt, R.C.; Rhodin, A.G.; de la Ossa-Velásquez, J.; Rueda, J.N. \& Mittermeier, C.G. 2007. Las tortugas e los cocodrilianos de los países andinos del trópico. Serie de guias tropicales de campo, Conservación Internacional Editorial Panamericana, Formas e Impresos, Bogotá. 538p.

Souza, E.R.B.; Zago, R.; Garcia, J.; Farias, J.G.; Carvalho, S.E.M. \& Barroso, M.R. 2007. Efeito de métodos de escarificação do tegumento em sementes de Leucaena diversifolia. Pesquisa Agropecuária Tropical 37: 142-146.

Strong, J.N. \& Fragoso, J.M.V. 2006. Seed dispersal by Geochelone carbonaria and Geochelone denticulata in Northwestern Brazil. Biotropica 38: 683-686.

Tadros, M.J.; Samarah, N.H. \& Alqudah, A.M. 2011. Effect of different pre-sowing seed treatments on the germination of Leucaena leucocephala (Lam.) and Acacia farnesiana (L.). New Forests 42: 397-407.

Teles, M.M.; Alves, A.A.; Oliveira, J.C.G. \& Bezerra, A.M.E. 2000. Métodos para quebra da dormência em sementes de Leucena (Leucaena leucocephala (Lam.) de Wit1. Revista Brasileira de Zootecnia 29: 387-391.

Traveset, A. \& Verdú, M. 2002. A meta-analysis of the effect of gut treatment on seed germination. In: Levey, D.J.; Silva, W.R. \& Galetti, M. (eds.). Seed dispersal and frugivory: ecology, evolution and conservation. CABI, Wallingford. Pp 339-350.

Wang, E.; Donatti, C.I.; Ferreira, V.L.; Raizer, J. \& Himmelstein, J. 2011. Food habits and notes on the biology of Chelonoidis carbonaria (Spix 1824) (Testudinidae, Chelonia) in the Southern Pantanal, Brazil. South American Journal of Herpetology 6: 11-19. 